\title{
ANALISIS KUALITAS AIR TANAH AKIBAT PENGARUH SUNGAI KLAMPOK YANG TERCEMAR LIMBAH INDUSTRI DI KECAMATAN BERGAS SEMARANG JAWA TENGAH \\ (Analysis of Groundwater Quality Due to Effect Klampok River that was Contaminated Industrial Waste in Bergas Semarang Central Java)
}

\author{
Sepridawati Siregar* dan Desi Kiswiranti \\ ${ }^{1}$ Jurusan Geologi, Fakultas Teknologi Mineral, IST Akprind Yogyakarta, Jalan Kalisahak No. 28 \\ Kompleks Balapan, Kota Yogyakarta, 55222.
}

"Penulis korespondensi. Tel: +6281949051477. Email: sepridawati_srg@yahoo.co.id.

Diterima: 22 Oktober 2018

Disetujui: 29 November 2019

\begin{abstract}
Abstrak
Sungai Klampok mengalir melalui Kecamatan Bergas dan sekelilingnya terdapat beberapa industri sehingga mengakibatkan sungai tersebut tercemar karena menjadi badan penerima air limbah. Akibat penurunan kualitas air Sungai Klampok akan berimbas pada penurunan kualitas air tanah yang digunakan oleh penduduk sekitar sungai tersebut. Penelitian ini bertujuan untuk mengetahui kualitas air tanah yang berada di sekitar Sungai Klampok sebagai akibat adanya pengaruh beban pencemaran oleh air limbah industri berdasarkan Permenkes No. 416/MENKES/PER/IX/1990 tentang persyaratan kualitas air bersih. Lokasi pengambilan sampel air sungai dibagi menjadi 3 stasiun (LK1, LK2 dan LK3) sedangkan untuk sampel airtanah dari rumah-rumah penduduk dilakukan pada 6 titik yaitu 3 titik di daerah utara dari Sungai Klampok (U1,U2, U3) dan 3 titik di daerah selatan dari Sungai Klampok (S1,S2, S3). Pengambilan sampel dilakukan pada musim kemarau. Dari hasil uji kualitas air sungai, pencemaran yang terjadi pada air sungai Klampok masuk dalam kategori tercemar ringan-sedang. Sedangkan hasil uji kualitas air tanah masih berada di bawah baku mutu yang disyaratkan oleh Permenkes No. 416/MENKES/PER/IX/1990, sehingga penurunan kualitas air sungai Klampok tidak mempengaruhi kualitas air tanah di sekitar sungai tersebut.
\end{abstract}

Kata kunci: air sungai, air tanah, baku mutu, limbah, Sungai Klampok.

\begin{abstract}
The Klampok River flows through the Bergas Subdistrict and there are a number of industries around it, causing the river to become polluted because it becomes the body of the recipient of wastewater. As a result of the decline in the quality of the water in the Klampok River, it will impact on the quality of groundwater used by residents around the river. This study aims to determine the quality of groundwater around the Klampok River as a result of the influence of pollution load by industrial wastewater based on Permenkes No. 416 / MENKES / PER / IX / 1990 concerning requirements for clean water quality. The location of river water sampling is divided into 3 stations (LK1, LK2, and LK3) while for groundwater samples from residential houses is carried out at 6 points, namely 3 points in the northern area of Klampok River (U1, U2, U3) and 3 points in the area south of the Klampok River (S1, S2, S3). Sampling is done in the dry season. From the results of the test of river water quality, pollution that occurs in Klampok river water is categorized as mild-moderate polluted. While the results of groundwater quality testing are still below the quality standards required by Permenkes No. 416 / MENKES / PER / IX / 1990 so that the decline in the water quality of the Klampok river does not affect the quality of groundwater around the river.
\end{abstract}

Keywords: river water, groundwater, quality standard, waste, Klampok river.

\section{PENDAHULUAN}

Air merupakan suatu kebutuhan pokok utama bagi kelangsungan hidup manusia, hewan maupun tumbuh-tumbuhan. Meskipun air merupakan suatu sumber daya alam yang dapat diperbaharui (renewable) namun tetap terbatas bergantung pada ruang dan waktu. Begitu juga dengan air sungai yang mempunyai fungsi serbaguna bagi kehidupan dan penghidupan manusia. Fungsi sungai antara lain sebagai sumber air minum, sarana transportasi, sumber irigasi, perikanan dan lain sebagainya
(Effendi, 2007). Aktivitas manusia inilah yang menyebabkan sungai menjadi rentan terhadap pencemaran air. Begitupula pertumbuhan industri dapat menyebabkan dampak penurunan kualitas lingkungan (Endriani, 2010). Pengaruh aktivitas manusia ini sangat berperan terhadap kualitas air sungai juga telah banyak dilaporkan seperti di sungai Gajahwong Yogyakarta akibat perilaku penduduk dalam membuang limbah (Risyanto dan Widyastuti, 2004). Arianti dkk (2012) juga melaporkan penurunan kualitas lingkungan di sungai Galeh Semarang, yang terutama akibat 
aktivitas pertanian yang berlebihan. Kajian Kadim dkk (2013) juga melaporkan aktivitas pertanian sehingga menimbulkan pencemaran di sungai Umbulrejo Malang.

Lokasi Kabupaten Semarang dilalui jalur-jalur yang menghubungkan pusat-pusat perkembangan wilayah di Jawa Tengah yaitu Semarang, Surakarta dan Yogyakarta, menjadikan Kabupaten Semarang sebagai lokasi yang cukup strategis dan menjadi salah satu faktor pendorong perkembangan industri. Salah satu wilayah yang menunjukkan perkembangan pesat dalam industri di Kabupaten Semarang adalah Kecamatan Bergas. Perkembangan industri di Bergas disebabkan karena faktor tingginya penerimaan masyarakat terhadap pembangunan industri, dukungan aksesabilitas, ketersediaan lahan untuk industri serta dukungan pemerintah (Abdullah, 2010). Berdasarkan hasil penelitian Handayani (2007), diketahui bahwa, Kecamatan Bergas memiliki 58 industri besar yang tersebar dibeberapa desa meliputi desa Wujil (1 industri), Bergas Lor (1 industri), Bergas Kidul (5 industri), Randu Gunting (2 industri), Jatijajar (1 industri), Diawak (1 industri), Ngempon (26 industri), Karangjati (19 industri) dan Wringin Putih (2 industri).

Suatu sungai dikatakan tercemar, jika kualitas airnya sudah tidak sesuai dengan peruntukannya, yang didasarkan pada baku mutu kualitas air sesuai kelas berdasarkan Peraturan Pemerintah Nomor 82 Tahun 2001 tentang Pengelolaan Kualitas Air dan Pengendalian Pencemaran Air. Hal tersebut terjadi pada Daerah Aliran Sungai (DAS) Klampok yang mengalir di Desa Diwak dan Kelurahan Ngempon, Bergas telah tercemar limbah dan telah menurun kualitasnya. Sungai Klampok adalah sungai yang menjadi badan air penerima buangan air limbah dari sejumlah industri di Kecamatan Bergas. Dengan menurunnya kualitas air sungai tersebut berimbas juga pada penurunan kualitas air tanah/sumur penduduk sekitar sungai tersebut. Akan tetapi, kebanyakan penduduknya tetap menggunakan air dari sumur dan Sungai Klampok untuk kegiatan rumah tangga.

Hasil kajian Organisasi Pelestari Sungai Indonesia (OPSI) juga menyebutkan, pencemaran Sungai Klampok diduga bersumber dari empat perusahaan. Oleh karena itu sebagian besar kawasan industri tersebut, saat ini tengah menghadapi ancaman kerusakan lingkungan yang serius dan pencemaran tersebut bukan hanya merusak ekosistem perairan sungai tetapi sudah merambat ke kualitas air tanah. Untuk itu perlu dilakukan analisis dan pemantauan kualitas air sungai dan airtanah di area sungai Klampok Kecamatan Bergas Semarang ini, khususnya pada saat musim kemarau.

\section{METODE PENELITIAN}

\section{Waktu dan Lokasi}

Penelitian dilaksanakan di daerah sekitar sungai Klampok, Kecamatan Bergas, Kabupaten Semarang. Sampel yang diambil adalah sampel air sungai Klampok dan sampel air tanah yang dekat dengan pemukiman disekitar sungai Klampok. Pengambilan sampel dilakukan pada musim kemarau (Maret-Juli 2018). Lokasi penelitian tersebut dapat dilihat pada Gambar 1.

\section{Prosedur}

Rancangan penelitian yang dilakukan sebagai berikut: studi literatur dikerjakan untuk memperoleh informasi yang berhubungan dengan judul penelitian, orientasi lapangan, menentukan lokasi penelitian, menentukan obyek dan titik pengambilan sampel penelitian, pengumpulan data primer dan data sekunder, menganalisis data. Parameter yang diukur: air sungai (BOD, COD, TSS, DO, suhu, pH, Sulfat, Nitrat, debit air dan logam berat $\mathrm{Pb}, \mathrm{Cd}, \mathrm{Mn}, \mathrm{Se}, \mathrm{Co}, \mathrm{Zn}, \mathrm{Fe}, \mathrm{As}, \mathrm{Hg}$ dan $\mathrm{Cu}$ ) dan airtanah: Fisika (bau, TDS, kekeruhan, rasa, suhu, warna), Kimia ( $\mathrm{pH}, \mathrm{CaCO} 3, \mathrm{Fe}$, Flourida, Cd, Klorida, Hg, Mangan, Nitrat, Zn, Pb, Salenium, Sianida, Sulfat) dam Mikrobiologi (Total Koliform (MPN)). Analisis Laboratorium menggunakan alat Gravimetri, Potensiometer, Titrimetri, Reflux tertutup dan Atomic Absorption Spectroscopy (AAS).

Stasiun penelitian ditentukan dengan menggunakan sample survey method, yaitu metode pengambilan sampel yang dilakukan dengan membagi daerah penelitian menjadi stasiun-stasiun yang diharapkan dapat mewakili populasi penelitian. Penentuan titik pengambilan kualitas air sungai dan airtanah didasarkan pada pertimbangan kemudahan akses, biaya dan waktu sehingga ditentukan titik-titik yang dianggap mewakili kualitas air sungai dan airtanah akibat limbah industri. Pengambilan sampel air sungai dilakukan pada 3 titik yaitu hulu, tengah dan hilir (3 stasiun: LK1, LK2 dan LK3) dari Sungai Klampok.

Pengambilan sampel airtanah dari rumahrumah penduduk dilakukan pada 6 titik yaitu 3 titik di daerah utara dari Sungai Klampok (U1,U2, U3) dan 3 titik di daerah selatan dari Sungai Klampok (S1,S2, S3). Sampel air sungai dan air tanah untuk setiap titik sampling ditempatkan dalam botol plastik volume 1 liter sejumlah 1 buah dan botol plastik 0,5 liter sejumlah 3 buah. Sampel air sungai yang akan dianalisis di laboratorium dengan menggunakan metode yang sesuai ketentuan SNI. Untuk sampel airtanah yang akan dianalisis di laboratorium dengan menggunakan metode yang sesuai ketentuan SNI. Teknik pengujian masingmasing parameter dapat dilihat pada Tabel 1 . 
Tabel 1. Parameter kualitas sampel dan metode analisis air sungai dan airtanah.

\begin{tabular}{lll}
\hline \multicolumn{1}{c}{ Parameter analisis } & \multicolumn{1}{c}{ Satuan } & \multicolumn{1}{c}{ Perlakuan } \\
\hline Air sungai & & \multicolumn{1}{c}{ Pemuaian } \\
Suhu & ${ }^{\circ} \mathrm{C}$ & Potensiometer \\
$\mathrm{pH}$ & - & Gravimetri \\
$\mathrm{TSS}$ & $\mathrm{mg}$ & Titrimetri \\
$\mathrm{BOD}$ & $\mathrm{mg} / \mathrm{L}$ & Reflux tertutup \\
$\mathrm{COD}$ & $\mathrm{mg} / \mathrm{L}$ & Titrimetri \\
DO & $\mathrm{mg} / \mathrm{L}$ & AAS \\
Logam berat & $\mathrm{ppm}$ & \\
\hline Air tanah & & Penginderaan \\
Bau & - & Pemuaian \\
Suhu & ${ }^{\circ} \mathrm{C}$ & Potensiometer \\
pH & - & Gravimetri \\
Jumlah zat padat terlarut $(\mathrm{TDS})$ & $\mathrm{mg} / \mathrm{L}$ & Potensiometer \\
Kekeruhan & $\mathrm{Skala}$ NTU & Penginderaan \\
Rasa & - & Potensiometer \\
Warna & Skala TCU & Metode Titrasi EDTA \\
Kesadahan CaCO & mg/L & AAS \\
Logam berat & ppm & \\
Total koliform $\left(\mathrm{MPN}_{3}\right.$ & Jumlah/100 mL & \\
\hline
\end{tabular}
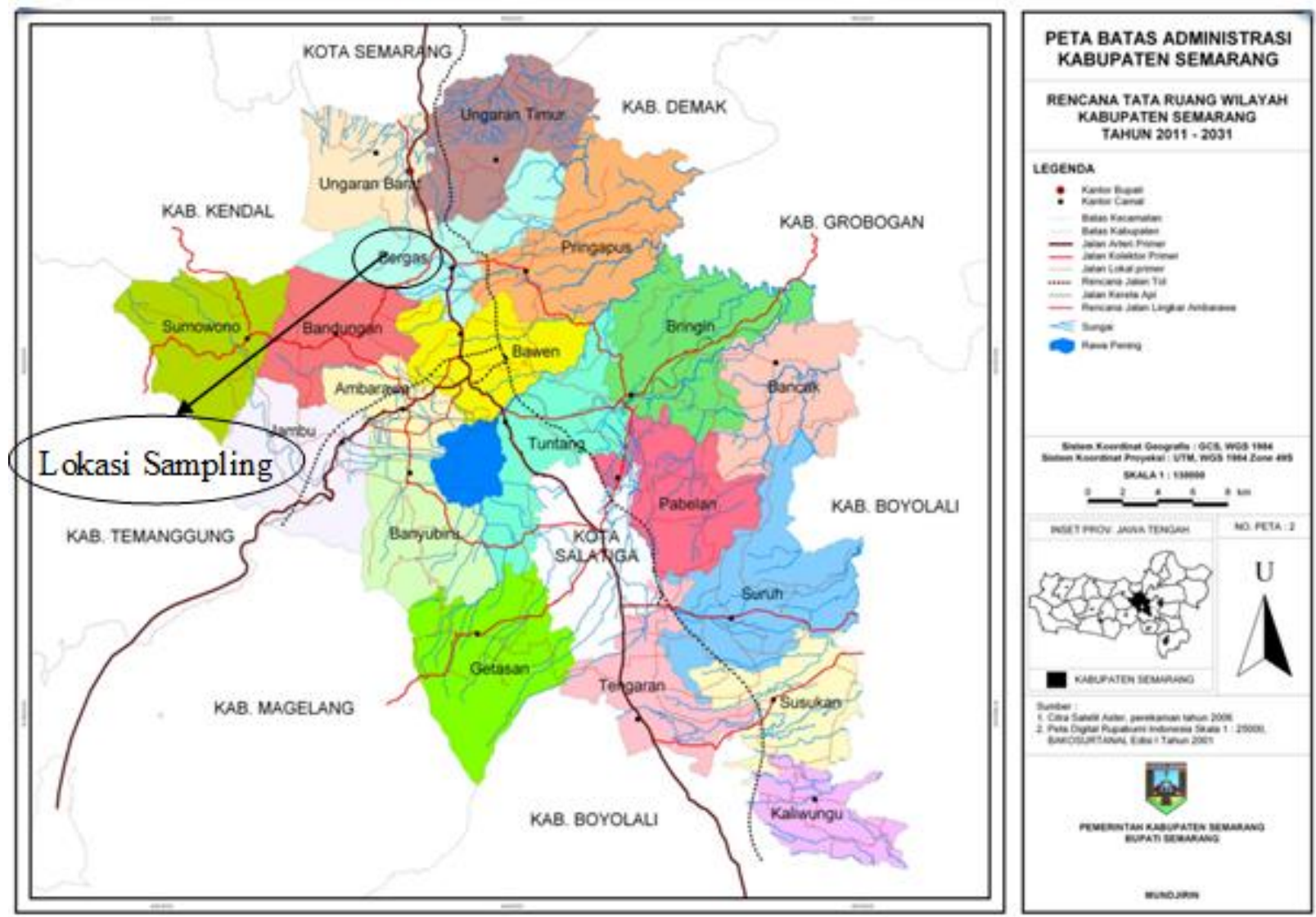

Gambar 1. Peta lokasi penelitian di Kecamatan Bergas, Kabupaten Semarang, Jawa Tengah.

\section{HASIL DAN PEMBAHASAN}

\section{Hasil Analisis Air Sungai Klampok}

Sampling air sungai Klampok dan air tanah dilakukan pada musim kemarau bulan April dan Mei 2018 yang berlokasi di Desa Diwak, Kelurahan Ngempon, Kec. Bergas, Kab. Semarang, Jawa Tengah. Berdasarkan pengamatan di lapangan, jenis industri yang air limbahnya menjadi sumber pencemar point sources discharges yaitu minuman beralkohol, minuman ringan dan jamu. Data jenis dan lokasi disajikan pada Tabel 2.

Titik lokasi pengambilan sampel air sungai Klampok dan airtanah yang berlokasi di Desa Diwak, Kelurahan Ngempon, Kec. Bergas, Kab. Semarang, Jawa Tengah, dapat dilihat pada Gambar 2. 
Tabel 2. Jenis industri pada daerah penelitian.

\begin{tabular}{lll}
\hline \multicolumn{1}{c}{ Industri } & \multicolumn{1}{c}{ Jenis Industri } & \multicolumn{1}{c}{ Lokasi } \\
\hline Industri A & Minuman Beralkohol & Desa Bergas Kidul \\
Industri B & Minuman Ringan & Desa Bergas Kidul \\
Industri C & jamu & Desa Bergas Kidul \& Diwak \\
\hline
\end{tabular}

Sumber: Dinas Perindustrian Kabupaten Semarang (Anonim, 2010).

Tabel 3. Hasil analisis sampel air Sungai Klampok.

\begin{tabular}{llllllllr}
\hline \multicolumn{1}{c}{ Titik Sampling } & $\begin{array}{c}\text { Suhu } \\
{ }^{\circ} \mathrm{C}\end{array}$ & $\mathrm{pH}$ & $\begin{array}{c}\mathrm{TSS} \\
(\mathrm{mg} / \mathrm{L})\end{array}$ & $\begin{array}{c}\mathrm{COD} \\
(\mathrm{mg} / \mathrm{L})\end{array}$ & $\begin{array}{c}\mathrm{BOD} \\
(\mathrm{mg} / \mathrm{L})\end{array}$ & $\begin{array}{c}\mathrm{DO} \\
(\mathrm{mg} / \mathrm{L})\end{array}$ & $\begin{array}{c}\text { Sulfat } \\
(\mathrm{mg} / \mathrm{L})\end{array}$ & $\begin{array}{c}\mathrm{NO}_{3}-\mathrm{N} \\
(\mathrm{mg} / \mathrm{L})\end{array}$ \\
\hline LK1 (Hulu) & 28,6 & 9,0 & 75 & 74 & 25 & 15,2 & 2,32 & 0,08 \\
LK2 (Tengah) & 29,2 & 10,8 & 150 & 102 & 40 & 5,63 & 5,64 & 0,13 \\
LK3 (Hilir) & 27,5 & 9,2 & 105 & 86 & 30 & 10,4 & 4,87 & 0,09 \\
\hline
\end{tabular}

Tabel 4. Hasil analisis logam air Sungai Klampok.

\begin{tabular}{lcccccccccc}
\hline \multirow{2}{*}{ Kode Sampel } & \multicolumn{10}{c}{ Konsentrasi (ppm) } \\
\cline { 2 - 12 } & $\mathrm{Pb}$ & $\mathrm{Cd}$ & $\mathrm{Mn}$ & $\mathrm{Se}$ & $\mathrm{Co}$ & $\mathrm{Zn}$ & $\mathrm{Fe}$ & $\mathrm{As}$ & $\mathrm{Hg}$ & $\mathrm{Cu}$ \\
\hline LK1 (Hulu) & 0,001 & 0,004 & 0,25 & 0,026 & 0,13 & 0,16 & 60 & 0,06 & ttd & 0,18 \\
LK2 (Tengah) & 0,001 & 0,008 & 0,26 & 0,047 & 0,37 & 0,13 & 101 & 0,27 & ttd & 0,40 \\
LK3 (Hilir) & 0,003 & 0,008 & 0,20 & 0,043 & 0,36 & 0,13 & 97 & 0,29 & ttd & 0,37 \\
\hline
\end{tabular}

Keterangan: $\operatorname{ttd}=$ tidak terdeteksi

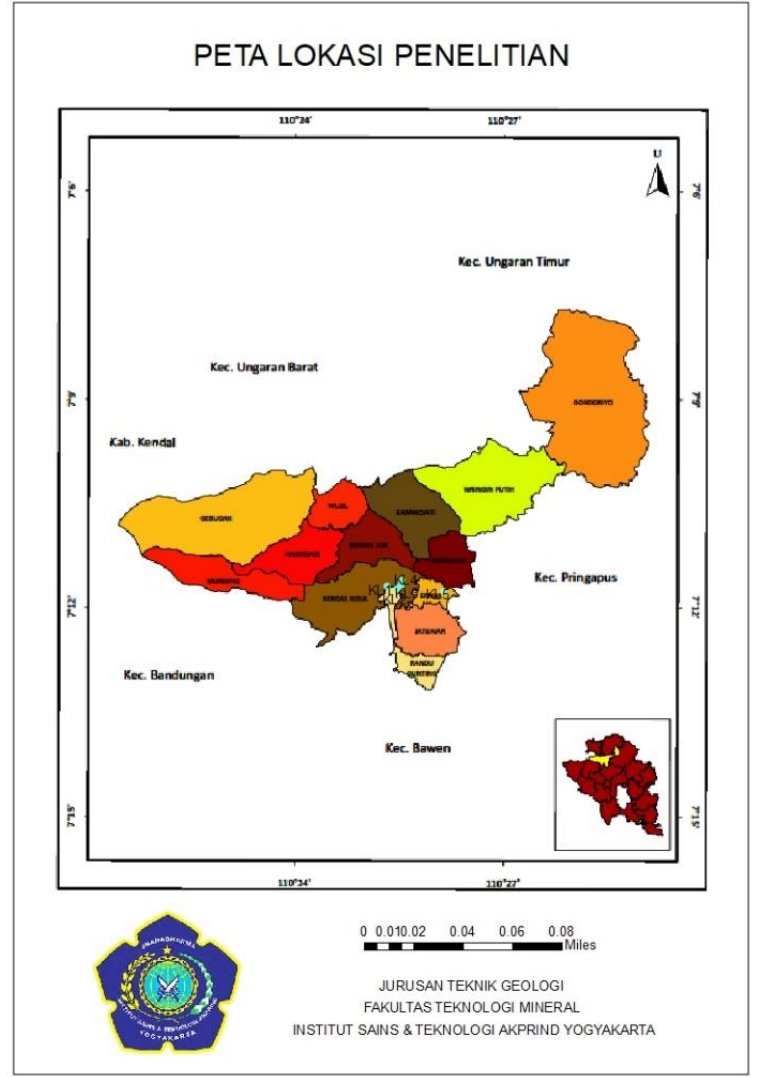

Gambar 2. Titik lokasi sampling air sungai Klampok dan air tanah di Desa Diwak, Kelurahan Ngempon, Kecamatan. Bergas, Kab. Semarang, Jawa Tengah.

Dari Gambar 2 dapat dilihat titik lokasi pengambilan sampel air sungai dan airtanah. Pada lokasi sampling tersebut industri yang paling mendekati adalah tiga perusahaan minuman dan jamu. Parameter suhu dan $\mathrm{pH}$ dari air sungai dilakukan pengukuran langsung di lapangan. Hasil analisis yang diperoleh untuk air sungai Klampok dapat dilihat lebih jelas pada Tabel 3.

Air Sungai Klampok memiliki suhu yang normal dengan rata-rata suhunya $28,4^{\circ} \mathrm{C}$ (Tabel 3). Untuk derajat keasaman air $(\mathrm{pH})$ sungai Klampok tiap titik memiliki nilai yang berbeda di mana titik LK2 (tengah) yang merupakan titik yang dilalui oleh berbagai industri memiliki nilai $\mathrm{pH}$ tertinggi yaitu 10,8. pH sungai Klampok termasuk dalam kategori basa di mana memiliki nilai di atas 7 . Begitu juga Untuk nilai TSS, COD, BOD, Sulfat dan Nitrat mengalami peningkatan di titik LK2 dan mengalami penurunan di titik LK3. Untuk nilai DO mengalami penurunan di titik LK2.

Air Sungai Klampok memiliki kandungan logam yang berbeda di setiap lokasi titik pengambilan sampel (Tabel 4). Umumnya kandungan logam meningkat pada titik LK2 dan menurun di titik LK3 kecuali nilai $\mathrm{Cd}$ dan $\mathrm{Zn}$ yang konstan di titik $\mathrm{KL} 3, \mathrm{~Pb}$ dan As yang mengalami peningkatan pada titik LK3. Untuk kandungan $\mathrm{Hg}$ tidak terdeteksi nilainya karena nilai $\mathrm{Hg}$ yang sangat kecil sekali di dalam sampel sehingga tidak terdeteksi dengan menggunakan alat AAS.

Berdasarkan Peraturan Pemerintah No. 82 Tahun 2001 Tentang Pengelolaan Kualitas Air dan Pengendalian Pencemaran Air menurut Kriteria Mutu Air Berdasarkan Kelas, bahwa air sungai Klampok tidak dapat digunakan untuk kelas I, II dan III, karena hasil analisis terhadap sampel air sungai Klampok melebihi baku mutu yang dipersyaratkan. Di mana Kelas I adalah air yang peruntukkannya dapat digunakan untuk air baku air minum, kelas II yaitu air yang peruntukkannya dapat digunakan untuk prasarana/sarana rekreasi 
air, pembudidayaan ikan air tawar, peternakan, air untuk mengairi pertanaman dan kelas tiga yaitu air yang peruntukannya dapat digunakan untuk pembudidayaan ikan air tawar, peternakan, air untuk mengairi pertanaman, dan atau peruntukkan lain yang mempersyaratkan mutu air yang sama dengan kegunaan tersebut. Air sungai Klampok hanya disarankan penggunaannya pada kelas IV yaitu air yang peruntukannya dapat digunakan untuk mengairi pertanaman dan atau peruntukan lain yang mempersyaratkan mutu air yang sama dengan kegunaan tersebut. Hasil analisis ini sesuai dengan penelitian terdahulu, di mana Siregar dkk. (2016), menyatakan secara umum kualitas air Sungai Klampok tidak memenuhi kriteria air Kelas I, II, III karena pada semua titik sebagian besar parameter yang diuji melebihi baku mutu berdasarkan PP Nomor 82 Tahun 2001. Jika dibandingkan dengan kondisi lain, seperti sungai Serayu (Priyambada, 2008) maka kualitas di sana relatif masih aman karena pengaruh lebih hanya karena perubahan fungsi tata guna lahan belum begitu tinggi.

\section{Hasil Analisis Sampel Airtanah}

Sampling airtanah dilakukan untuk mengetahui seberapa besar pengaruh pencemaran air sungai Klampok terhadap konsentrasi airtanah yang ada disekitar air sungai tersebut. Sampel air tanah ini diambil dari sumber air sumur milik warga setempat dengan jarak yang tidak terlalu jauh dari aliran sungai Klampok, yaitu sekitar 500 meter sampai $1 \mathrm{~km}$ dari pinggir sungai Klampok. Sama halnya dengan air sungai Klampok, Parameter suhu dan $\mathrm{pH}$ dari airtanah juga dilakukan pengukuran langsung dilapangan. Begitu juga dengan rasa dan bau dari airtanah. Hasil analisis yang diperoleh untuk airtanah di daerah sekitar sungai Klampok dapat dilihat pada Tabel 5. Berdasarkan Peraturan Menteri Kesehatan Republik Indonesia No. 416/MENKES/PER/IX/1990 tentang Daftar Persyaratan Kualitas Air Bersih, hasil analisis dari sampel airtanah menunjukkan nilai yang masih memenuhi baku mutu sehingga dapat digunakan untuk memenuhi kebutuhan air bersih sehari-hari.

Tabel 5. Hasil analisis airtanah sekitar aliran air sungai Klampok.

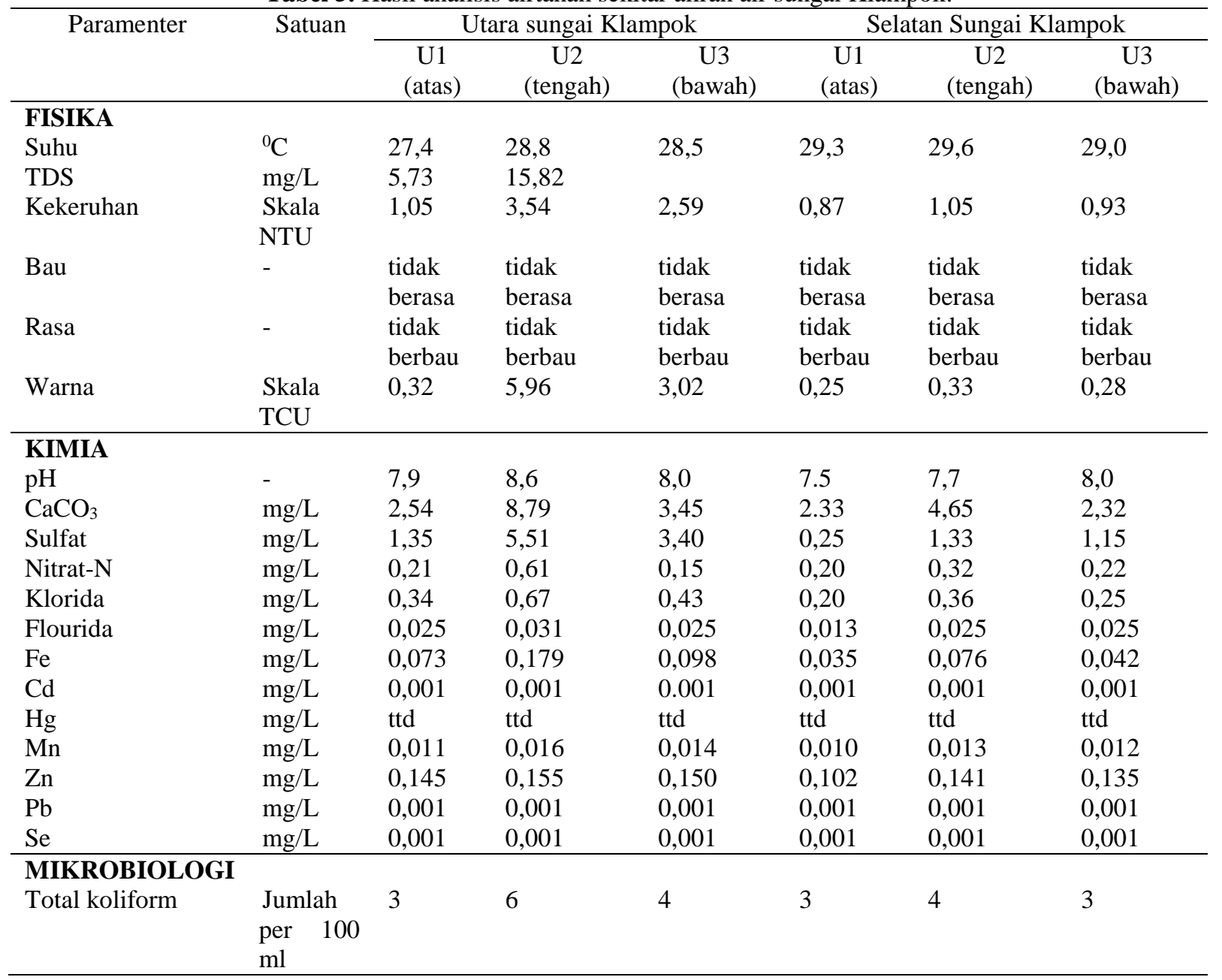

Keterangan: $\operatorname{ttd}=$ tidak terdeteksi 


\section{KESIMPULAN}

Hasil analisis kualitas air Sungai Klampok dapat digunakan sebagai petunjuk adanya pengaruh beban pencemaran oleh air limbah indsutri yang ada di sekitar aliran sungai tersebut. Berdasarkan Peraturan Pemerintah No. 82 Tahun 2001, dari hasil analisis diketahui air sungai Klampok tidak dapat digunakan untuk kelas I, II dan III, akan tetapi dapat digunakan pada kelas IV yaitu air yang peruntukkannya dapat digunakan untuk mengairi pertanaman dan atau peruntukan lain yang mempersyaratkan mutu air yang sama dengan kegunaan tersebut. Berdasarkan Peraturan Menteri Kesehatan RI No. 416/MENKES/PER/IX/1990, hasil analisis dari sampel airtanah menunjukkan nilai yang masih memenuhi baku mutu sehingga dapat digunakan untuk memenuhi kebutuhan air bersih sehari-hari.

\section{DAFTAR PUSTAKA}

Abdullah, 2010. Pengaruh Perkembangan Industri Terhadap Pola Pemanfaatan Lahan di Wilayah Kecamatan Bergas Kabupaten Semarang, Tesis, MPWK, Undip.

Anonim, 2010. Dinas Perindustrian \& Perdagangan Kabupaten Semarang. Ungaran.

Arianti, F.D., Suratman, Martono, E., dan Suprayogi, S., 2012. Dampak Pengelolaan Lahan Pertanian Terhadap Hasil Sedimen di Daerah Aliran Sungai Galeh Kabupaten Semarang. J. Manusia \& Lingkungan, 19(3):238-246.
Effendi, H. 2007. Telaah Kualitas Air bagi Pengelolaan Sumber Daya dan Lingkungan Perairan, Yogyakarta.

Endriani, 2010. Sifat Fisika dan Kadar Air Tanah Akibat Penerapan Olah Tanah Konservasi, Hidrolitan, 1(1):26-34.

Handayani, S.I.K., 2007. Pemetaan Persebaran Industri Besar di Kecamatan Bergas Kabupaten Semarang menggunakan Sistem Informasi Geografis. Skripsi. Universitas Negeri Semarang.

Kadim, M. K., Sudaryanti, S., dan Yuli, E.H., 2013. Pencemaran Residu Pestisida di Sungai Umbulrejo Kecamatan Dampit Kabupaten Malang. J. Manusia \& Lingkungan, 20(3):262268.

Priyambada, A., 2008. Analisis Pengaruh Perbedaan Fungsi Tata Guna Lahan Terhadap Beban Cemaran BOD Sungai (Studi Kasus Sungai Serayu, Jawa Tengah). Jurnal Presipitasi, 5(2):55-62.

Risyanto, R., dan Widyastuti, M., 2004. Pengaruh Perilaku Penduduk dalam Membuang Limbah Terhadap Kualitas Air Sungai Gajahwong. $J$. Manusia \& Lingkungan, 11(2):73-85.

Siregar, S., Dzakiya, N., Idiawati, N., Kiswiranti, D. 2016, Pengaruh Air Sungai yang Tercemar Limbah Terhadap Kualitas Tanah di Sekitar Sungai Klampok, Prosiding Seminar Nasional Aplikasi Sains \& Teknologi (SNAST) AKPRIND, Yogyakarta 26 November 2016.

Zakaria, I., 2015. Sungai Klampok Tercemar, 8 Pabrik Disorot Terkait Pencemaran Limbah. http://radarsemarang.com/jawa-tengahjogja/ungaran/sungai-klampok-tercemar-8pabrik-disorot/ (diakses : 16 April 2017). 